\title{
GEOCRONOLOGIA E GEOQUÍMICA DE ORTOGNAISSES DA REGIÃO ENTRE IPORÁ E FIRMINÓPOLIS: IMPLICAÇÕES PARA A EVOLUÇÃO DO ARCO MAGMÁTICO DE GOIÁS
}

\section{JOSENEUSA BRILHANTE RODRIGUES, SIMONE MARIA LIMA COSTA GIOIA E MÁRCIO MARTINS PIMENTEL*}

\begin{abstract}
GEOCHRONOLOGY AND GEOCHEMISTRY OF ORTHOGNEISSES OF THE IPORÁ-FIRMINÓPOLIS REGION: IMPLICATIONS FOR THE EVOLUTION OF THE GOIÁS MAGMATIC ARC In this study we report new Sm-Nd and Rb-Sr isotopic data and preliminary geochemical results for orhtogneissic and metavolcanic rocks units exposed roughly between the towns of Iporá and Firminópolis, southwestern Goiás.

Samples from orthogneisses adjacent to the Iporá volcano-sedimentary sequence yielded a Rb-Sr isochron age of $673 \pm 75 \mathrm{Ma}$, with initial ${ }^{87} \mathrm{Sr} /{ }^{86} \mathrm{Sr}$ ratio of $0.7048 \pm 0.0004 . \varepsilon_{\mathrm{Nd}}(\mathrm{T})$ values for these rocks are between ca. +0.4 and +1.9 and $\mathrm{T}_{\mathrm{DM}}$ ages are between 1.0 and $1.1 \mathrm{Ga}$, indicating the juvenile character of the parental magma. Trace element results also indicate the arc affinity of the magma. One felsic metavolcanic rock from the Iporá volcano-sedimentary sequence yielded an U-Pb zircon age of $636 \pm 6 \mathrm{Ma}$ and $\mathrm{T}_{\mathrm{DM}}$ model ages between 0.76 and $1.0 \mathrm{Ga}$. It represents the youngest volcanic example in the Goiás Magmatic Arc.

In the Fazenda Nova area, samples from tonalitic and dacitic units display juvenile Nd isotopic characteristics, with $\mathrm{T}_{\mathrm{DM}}$ model ages of 0.95 and $0.88 \mathrm{Ga}$, respectively. Further to the south, in the southern end of the Moiporá-Novo Brasil mylonitic zone, biotite gneisses and mylonites have substantially older $\mathrm{T}_{\mathrm{DM}}$ ages, ranging from ca. 1.7 to $3.2 \mathrm{Ga}$, indicating the presence of an older sialic fragment in that area. The gneisses in the Moiporá area together with the Ribeirão gneisses in the vicinity of Arenópolis and displaying Archaean model ages, represent the only two exposures of older terranes known in the Goiás Magmatic Arc.

The Firminópolis hornblende gneisses, in the eastern end of the area investigated, show arc-type geochemical signature and Nd isotopic characteristics (Sm-Nd whole-rock "errorchron" age of ca. $630 \mathrm{Ma}$ and $\mathrm{T}_{\mathrm{DM}}$ ages of $1.1-1.4 \mathrm{Ga}$ ) which indicate that the tonalitic protoliths were still part of the Neoproterozoic arc system.

The results indicate that the juvenile rock units belonging to the Goiás Magmatic Arc extend to the east as far as the Firminópolis area where gneisses with very primitive characteristics, similar to the Arenópolis, Matrinxã and Sanclerlândia orthogneisses, are exposed.

Keywords: orthogneisses, juvenile, Neoproterozoic, Goiás Magmatic Arc
\end{abstract}

RESUMO Nesse estudo são apresentados novos dados isotópicos Sm-Nd e Rb-Sr, além de resultados geoquímicos preliminares de unidades de ortognaisses e uma metavulcânica expostas entre as cidades de Iporá e Firminópolis no sudoeste de Goiás.

Amostras de ortognaisses da região de Iporá forneceram uma idade isocrônica $\mathrm{Rb}$-Sr em rocha total de $673 \pm 75 \mathrm{Ma}$, com razão ${ }^{87} \mathrm{Sr} /{ }^{86}$ inicial de $0,7048 \pm 0.0004$. Os valores de $\varepsilon_{\mathrm{Nd}}(\mathrm{T})$ para essas rochas estão entre ca. $+0,4$ e $+1,9$ e idades modelo ${ }_{\mathrm{DM}} \mathrm{T}$ entre 1,0 e $1,1 \mathrm{Ga}$, indicando o caráter juvenil do magma granítico original. A composição de elementos traços também aponta para o caráter de arco do magma. Uma amostra de rocha metavulcânica félsica da seqüência vulcanossedimentar de Iporá apresentou idade U-Pb em zircão de $636 \pm 6 \mathrm{Ma}$ e idades $\mathrm{T}_{\mathrm{DM}}$ de 0,77 e 1,0 Ga. Essa rocha representa a rocha metavulcânica mais jovem já datada no Arco Magmático de Goiás.

$\mathrm{Na}$ área de Fazenda Nova, amostras de unidades de rochas tonalíticas e dacíticas, também investigadas, mostram características juvenis em relação às composições isotópicas de $\mathrm{Nd}$, com idades modelo $\mathrm{T}_{\mathrm{DM}}$ de 0,95 e $0,88 \mathrm{Ga}$, respectivamente. Mais a sul, na extremidade sul do lineamento Moiporá-Novo Brasil, biotita gnaisses e milonitos indicaram idades $\mathrm{T}_{\mathrm{DM}}$ significativamente mais antigas, entre ca. 1,7 e 3,2 Ga, revelando a existência de um fragmento siálico mais antigo naquela localidade. Esses gnaisses e o gnaisse Ribeirão, nas vizinhanças de Arenópolis, com idades modelo arqueanas, representam as dois únicos exemplos conhecidos até o momento de exposições de terrenos mais antigos em meio às rochas juvenis do Arco Magmático de Goiás.

Os hornblenda gnaisses de Firminópolis, na extremidade leste da área investigada, mostram assinatura geoquímica de arco e características isotópicas de $\mathrm{Nd}$ ("errócrona" Sm-Nd com idade de ca. $630 \mathrm{Ma}$ e $\mathrm{T}_{\mathrm{DM}}$ entre 1,1 e 1,4 Ga) que indicam que os protólitos tonalíticos eram parte do sistema de arco Neoproterozóico.

Os resultados mostraram que o arco magmático de Goiás se estende para leste pelo menos até as proximidades de Firminópolis onde estão expostos ortognaisses tonalíticos primitivos, semelhantes petrográfica, química e isotopicamente aos gnaisses de Arenópolis, Matrinxã e Sanclerlândia.

Palavras - chaves: ortognaisses, juvenil, Neoproterozóico, Arco Magmático de Goiás

INTRODUÇÃ̃O Ao longo dos últimos anos, o conhecimento a respeito da evolução geodinâmica da Faixa Brasília se enriqueceu principalmente em função da incorporação de novos dados geocronológicos U-Pb e Sm-Nd. Por exemplo, os estudos geocronológicos, isotópicos e geoquímicos de Pimentel \& Fuck (1992a, b), Viana et al. (1995), Pimentel et al. (1997a), Rodrigues (1996) demonstram que nas regiões sudoeste e noroeste de Goiás expõem-se terrenos que correspondem a antigos arcos de ilha de idade neoproterozóica. Esses terrenos foram coletivamente incluídos no Arco Magmático de Goiás (Fuck et al. 1994).

Os dados geocronológicos mais recentes evidenciam a presença dessas rochas juvenis neoproterozóicas nas áreas de Arenópolis-Piranhas, sudoeste de Goiás, e de Mara Rosa-Porangatu, no noroeste do estado, caracterizando significativo evento de acreção crustal com formação de seqüências vulcanossedimentares do tipo arco de ilhas e rochas metaplutônicas tonalíticas/granodioríticas cálcio-alcalinas associadas. Entretanto, os dados disponíveis até o momento são insuficientes para conhecer em maior detalhe a estruturação interna do Arco Magmático de Goiás ou mesmo a localização e natureza de seus limites com os terrenos vizinhos mais antigos.

Neste trabalho são reportados dados geocronológicos, isotópicos e geoquímicos de unidades de rochas metavulcânicas e metaplutônicas do Arco Magmático de Goiás na região compreendida aproximadamente entre as vizinhanças das cidades de Arenópolis e Firminópolis, no sudoeste de Goiás (Fig. 1). Os resultados são comparados com outras áreas do Arco Magmático, na tentativa de melhor compreender a história evolutiva desse fragmento de crosta juvenil neoproterozóica na região central do Brasil.
GEOLOGIA REGIONAL A área investigada situa-se aproximadamente entre as cidades de Arenópolis e Firminópolis, no sudoeste de Goiás, na porção central da Província Tocantins (Fig. 1). Esta província estrutural representa uma região orogenética neoproterozóica formada pela convergência e encontro dos blocos continentais Amazônia, São-Francisco/Congo e, possivelmente, um terceiro bloco (Bloco Paraná), encoberto pelas rochas sedimentares da Bacia do Paraná. A amalgamação desses blocos continentais constitui parte do processo de aglutinação do Gondwana Ocidental no fim do Neoproterozóico (Brito Neves \& Cordani 1991, Trompette 1994).

A Província Tocantins é constituída por faixas de dobramentos neoproterozóicas conhecidas individualmente como faixas Brasília, Paraguai e Araguaia (Fig. la). A primeira desenvolveu-se no flanco oeste do Cráton do São Francisco e as últimas nas bordas sul e leste do Cráton Amazônico.

A Faixa Brasília, com extensão de ca. de $1000 \mathrm{~km}$ na direção norte-sul, constitui um cinturão de dobras e falhas de empurrão mostrando nítidas vergências tectônica e metamórfica em direção ao Cráton do São Francisco (Fig. 1b). É constituída mormente por diversas unidades de rochas metassedimentares, interpretadas coletivamente como uma seqüência de margem continental passiva (e.g. grupos Paranoá, Canastra, Araxá e Serra da Mesa e formações Ibiá e Vazante). Ainda que, no presente nível de conhecimento, diversos aspectos da evolução geodinâmica da Faixa Brasília sejam mal compreendidos, a sua geologia exibe diversas feições características de cadeias de montanhas modernas (Fuck et al 1993, Fuck et al. 1994): (a) mélange ofiolítica associada aos metassedimentos do Grupo Araxá (Drake Jr. 1980, Strieder \& Nilson 1992), cuja presença sugere que ao 


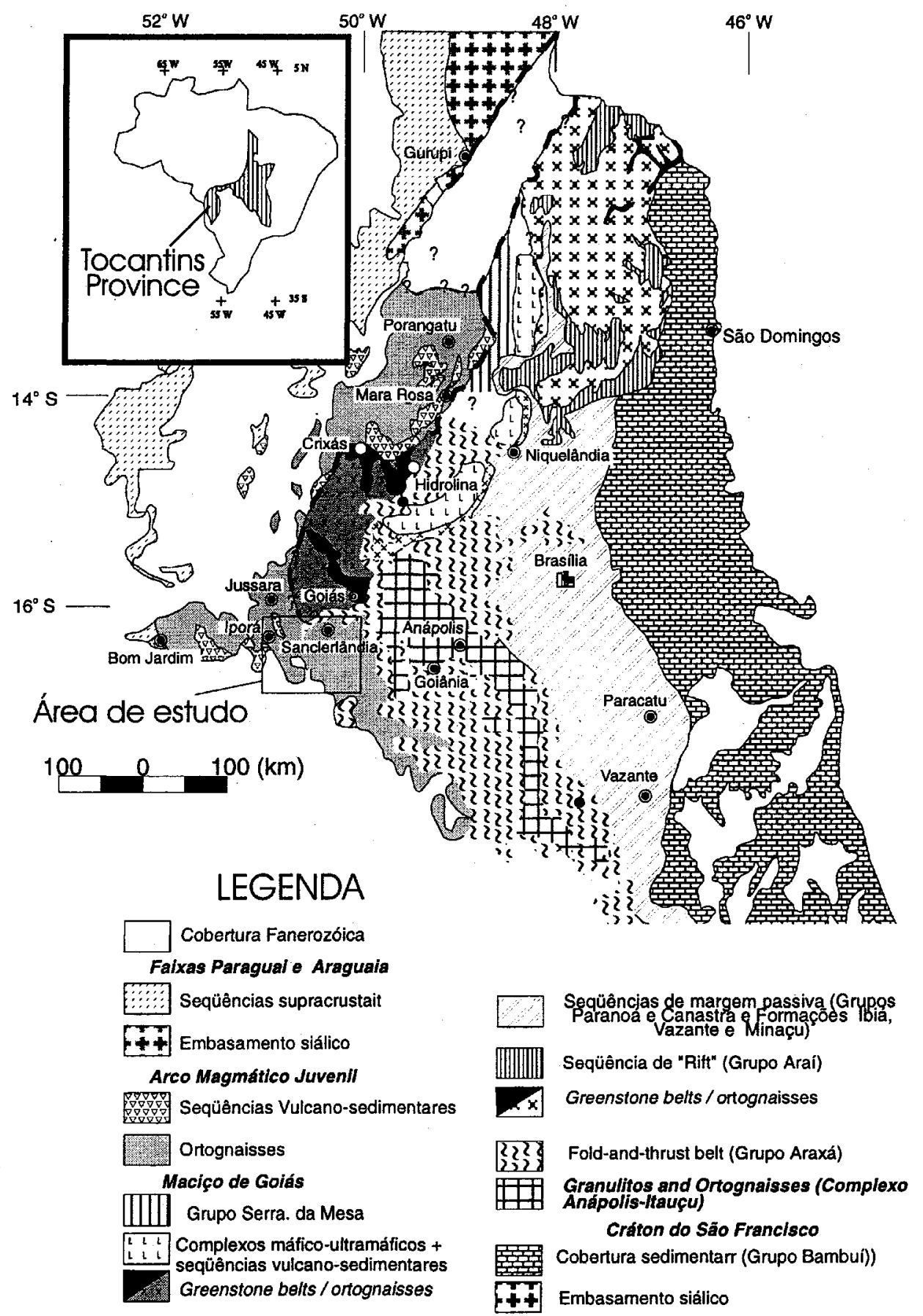

Figura l- Localização e mapa geológico-tectônico esquemático da porção sul da Província Tocantins mostrando as faixas dobradas e o Maciço de Goiás (a) e detalhe da porção leste da Província Tocantins mostrando as principais unidades geológicas constituindo a Faixa Brasília (b).

menos parte desse grupo seja interpretada como um antigo prisma de acreção; b - metamorfismo de alto grau de idade neoproterozóica, indicando espessamento crustal significativo durante a orogênese Brasiliana (Ferreira Filho et al. 1994, Suita et al 1994, Correia et al. 1997, Pimentel et al. 1998); c - magmatismo granítico do tipo sin-colisional associado a nappes no Grupo Araxá (Pimentel et al 1997b, Lacerda Filho et al 1995). Além disso, a presença de rochas juvenis (seqüências vulcanossedimentares e ortognaisses associados), formadas em arcos magmáticos durante o neoproterozóico, sugere que a Faixa Brasília evoluiu de maneira ensimática, em resposta à subducção de litosfera oceânica e fechamento de bacia oceânica, o que culminou com choque continental no fim do Neoproterozóico (Pimentel \& Fuck 1992a).

As unidades geológicas que constituem o Arco Magmático de Goiás estão expostas e têm sido estudadas em maior detalhe nas regiões de Arenópolis-Piranhas (sudoeste de Goiás; Pimentel \& Fuck 1986, 1987, Pimentel \& Fuck 1992a) e Mara Rosa (noroeste de Goiás;
Pimentel et al 1997a, Viana et al 1995). As seqüências vulcanossedimentares são formadas por rochas metavulcânicas máficas a félsicas, sendo que algumas mostram uma suíte cálcio-alcalina completa com metabasaltos, metandesitos, metadacitos e metariólitos (e.g. seqüências de Arenópolis e Bom Jardim), outras caracterizam-se pela predominância de rochas metavulcânicas máficas com poucos termos félsicos (e.g. seqüência de Mara Rosa), e ainda outras apresentam caráter bimodal (e.g. seqüências de Jaupaci e Iporá). O metamorfismo que afetou essas rochas é de fácies xisto verde (e.g. seqüência de Iporá) a anfibolito (e.g. seqüência de Mara Rosa). Terrenos de ortognaisses expostos entre as seqüências de rochas supracrustais são constituídos por metatonalitos, metagranodioritos e metagranitos. Mostram-se bastante deformados, localmente milonitizados, mas exibem algumas texturas e estruturas plutônicas bem preservadas.

Tanto na região sudoeste de Goiás, como na área de Mara Rosa, o Arco Magmático de Goiás é caracterizado por faixas de rochas metavulcânicas e metassedimentares com direções estruturais NNW e 
Tabela l-Dados geocronológicos e isotópicos para ortognaisses Arenópolis, Matrinxã e Sancerlândia do Arco Magmático de Goiás.

\begin{tabular}{|c|c|c|c|c|c|}
\hline UNIDADE & $\begin{array}{c}\text { IDADE } \\
(\mathrm{Ma})\end{array}$ & $\begin{array}{l}{ }^{87} \mathrm{Sr} /{ }^{36} \mathrm{Sr} \\
\text { inicial }\end{array}$ & $\mathrm{T}_{\mathrm{DM}}(\mathrm{Ga})$ & $\varepsilon_{\mathrm{Nd}_{\mathrm{d}}}(\mathrm{T})$ & Refer. \\
\hline Gnaisse Arenópolis & $\begin{array}{c}899 \pm 7^{4} \\
818 \pm 57^{b} \\
637^{c}\end{array}$ & 0,7042 & $1,0-1,2$ & $+1,9 /+3,2$ & 1,2 \\
\hline Gnaisse Matrinxã & ca. $895^{\mathrm{b}}$ & 0,7026 & 0,9 & $+6,0$ & 2 \\
\hline Gnaisse Sanclerlândia & ca. $940^{b}$ & 0,7025 & $0,9-1,0$ & $+4,0 /+6,0$ & 2 \\
\hline
\end{tabular}

NNE. Essas faixas são separadas entre si por ortognaisses de composição diorítica a granítica (dominam tonalitos e granodioritos) e granitos s.s. milonitizados. Os dados geocronológicos disponíveis até o momento revelam que os protólitos ígneos dessas rochas foram formados entre aproximadamente 900 e $640 \mathrm{Ma}$ (Pimentel et al. 1991, 1997, Pimentel \& Fuck 1994). As características petrográficas, geoquímicas e isotópicas de $\mathrm{Sr}$ e $\mathrm{Nd}$ indicam que os magmas originais formaram-se em ambientes de arcos de ilha intraoceânicos imaturos (as unidades mais antigas, 800-900 Ma), os quais evoluíram para situações de arco maduro ou, eventualmente, de margem continental ativa (Pimentel \& Fuck 1992b, Pimentel et al. 1998.)

Pimentel \& Fuck (1992a) e Pimentel et al (1997a) consideram que o Arco Magmático de Goiás representa, na verdade, uma colagem de diversos sistemas de arcos neoproterozóicos de natureza e idade distintas, que caracterizaram a margem oeste do continente São FranciscoCongo, e que ficou finalmente preservada na porç̃o interna da Faixa Brasília após a colisão entre os continentes Amazônia, São Francisco e Paraná.

\section{O ARCO MAGMÁTICO NA REGIÃO SUDOESTE DE GOIÁS}

Nos terrenos pré-cambrianos do sudoeste de Goiás ocorrem diversas faixas de rochas metavulcânicas e metassedimentares que, de oeste para leste, são conhecidas como seqüências vulcanossedimentares de Bom Jardim de Goiás, Arenópolis, Iporá, Amorinópolis e Jaupaci (Fig. 2). Essas seqüências são separadas entre si por áreas de ortognaisses e granitóides milonitizados, a semelhança do que ocorre em outros domínios do arco magmático. Todas essas unidades são justapostas ao longo de zonas de cisalhamento verticais de rejeito direcional, de direcão NNE e NNW que marcam o último evento deformacional da região. Abaixo estão relacionadas resumidamente as características principais dos mais importantes tipos de associações litológicas que constituem o Arco Magmático de Goiás no sudoeste do estado. Ortognaisses cálcicos a calcio-alcalinos São rochas de coloracão cinza, granulação média a grossa portadoras de hornblenda e/ou biotita com composicões tonalíticas e granodioríticas. Exemplos são os gnaisses Arenópolis, Matrinxã e Sanclerlândia, indicados na figura 2 (Simões 1984, Pimentel \& Fuck 1987, Amaro 1989). Segundo esses autores, mostram paragêneses metamórfícas da fácies epidoto anfibolito e, comumente, texturas e estruturas ígneas preservadas (enclaves máficos, texturas porfiríticas, etc.). São rochas metaluminosas, de caráter cálcico e cálcio-alcalino, caracterizadas pelos reduzidos teores de álcalis e altos conteúdos em $\mathrm{CaO}, \mathrm{MgO}, \mathrm{P}_{2} \mathrm{O}_{5}$ e $\mathrm{Al}_{2} \mathrm{O}_{3}$. Os baixos valores de $\mathrm{Rb} / \mathrm{Sr}, \mathrm{Zr}, \mathrm{Nb}, \mathrm{Y}$, Ce e Ga dos gnaisses de Arenópolis e Sanclerlândia são semelhantes aos de granitóides do tipo $\mathrm{M}$ de suítes plutônicas de arcos de ilha imaturos, enquanto que os ortognaisses Matrinxã mostram características geoquímicas intermediárias entre granitóides dos tipos M e I (Pimentel \& Fuck 1992b). Esses gnaisses mostram claro enriquecimento em elementos do tipo "LILE" (elementos litófilos de ions grandes) em relação a Nb, Y e Zr e ETR e baixa abundância de $\mathrm{Y}$ e $\mathrm{Yb}$, características típicas dos magmas gerados em ambientes de arco magmático. As características geoquímicas principais das rochas de Arenópolis e sua comparação com os ortognaisses Neoproterozóicos de Mara Rosa está mostrado na Figura 3.

Os dados geocronológicos dos gnaisses de Arenópolis, Matrinxã e Sanclerlândia mostram idades neoproterozóicas. A Tabela 1 apresenta um resumo desses dados, destacando-se a concentração de idades em torno de $900 \mathrm{Ma}$, as baixas razões ${ }^{87} \mathrm{Sr} /{ }^{86} \mathrm{Sr}$ iniciais $(0,7025-0,7042)$, os valores positivos de $\varepsilon_{\mathrm{Nd}}(\mathrm{T})(>\mathrm{r}+1,9)$ e de $\mathrm{T}_{\mathrm{Dy}}$ todos $<1,2 \mathrm{Ga}$. Esse conjunto de parâmetros indica o caráter juvenil dos protólitos dessas rochas.

Ortognaisses tonalíticos da região do Arco Magmático de Mara Rosa apresentam o mesmo padrão geocronológico, com idade U-Pb de ca. $860 \mathrm{Ma}$ e valores de $\mathrm{T}_{\mathrm{DM}}$ de ca. 1,0 Ga (Pimentel et al. 1997a).

Em função do seu caráter isotópica-e geoquimicamente primitivo (enriquecimento em elementos litófilos de ions grandes em relação a
$\mathrm{Nb}, \mathrm{Y}$ e Zr e ETR e baixa abundância de $\mathrm{Y}$ e $\mathrm{Yb}$ ), os protólitos dessas rochas são interpretados por Pimentel et al. (1998) como gerados em ambientes de arco de ilha intraoceânicos, sem a presença de crosta continental mais antiga.

Granitos Milonitizados Em toda região sudoeste de Goiás, e nas proximidades de Arenópolis, ocorrem corpos graníticos e, mais subordinadamente granodioríticos, milonitizados, que comumente formam faixas estreitas e alongadas em direcões entre NNE e NNW (e.g. granitos Macacos e Serra do Tatu, Fig. 2). Esses corpos são formados essencialmente por biotita granitos, com raros granodioritos. Neles a foliação milonítica é vertical ou subvertical e está fortemente desenvolvida nas proximidades dos seus contatos com as unidades vizinhas. Nas áreas mais internas dos corpos, feições ígneas primárias, tais como texturas porfiríticas estão preservadas.

Pouco se conhece a respeito da geocronologia desses corpos graníticos. Os dados disponíveis resumem-se aos obtidos pelo método $\mathrm{Rb}-\mathrm{Sr}$ em rocha total, além de uma dado Sm-Nd (Tabela 2).

As Seqüências Vulcanossedimentares Diversas faixas de rochas metavulcânicas e metassedimentares neoproterozóicas são conhecidas no oeste de Goiás. De oeste para leste (Fig. 2) estão individualizadas as seqüências de Bom Jardim de Goiás (Seer 1985), de Arenópolis (Pimentel \& Fuck 1986), Iporá e Amorinópolis (Danni \& Campos 1994, Franco et al. 1994) e Jaupaci (Amaro 1989). Mais a leste é ainda individualizada a seqüência vulcanossedimentar de Anicuns-Itaberaí, descrita por Lacerda Filho \& Oliveira (1994). Trata-se de uma seqüência contendo rochas vulcânicas toleiíticas e cálcio-alcalinas relacionadas a ambiente de arco de ilha. Sua idade ainda é desconhecida, entretanto dados isotópicos Sm-Nd recentes (Pimentel \& Fuck, dados inéditos) para rochas supracrustais (metavulcânicas?) da região de Pontalina, na extremidade sul da seqüência AnicunsItaberaí, revelaram idades modelo $\mathrm{T}_{\mathrm{DM}}$ entre 1.0 e $1.1 \mathrm{Ga}$, sugerindo que se trata de rochas pertencentes ao Arco Magmático de Goiás.

A Seqüência de Bom Jardim de Goiás é composta de metabasaltos, metandesitos e metariólitos, mostrando freqüentes estruturas e texturas primárias, tais como estruturas almofadadas, texturas piroclásticas e acamamento gradacional. Essas rochas metavulcânicas mostram características geoquímicas de rochas ígneas geradas em arcos de ilhas modernos (Seer 1985). As rochas metassedimentares do topo da seqüência incluem metaconglomerados, metarcóseos, metassiltitos e fílitos (Seer 1985). A seqüência vulcanossedimentar de Arenópolis é formada por duas unidades principais, separadas por uma estreita faixa de gnaisses, apresentando idades modelo TDM arqueanas (gnaisses Ribeirão, Pimentel 1992). A Unidade Córrego Santo Antônio ocupa a porção ocidental da seqüência e é composta de metapelitos (micaxistos com granada, estaurolita, cianita e sillimanita) associados a diversos corpos máfico-ultramáficos, lentes de mármores, rochas calcissilicáticas, metacherts e anfibolitos finos. Essa unidade é interpretada como um prisma de acreção e os corpos máfico-ultramáficos como fragmentos de suítes ofiolíticas (Pimentel \& Fuck 1986). A Unidade Corrego da Onça, a leste do gnaisse Ribeirão, é formada dominantemente por rochas metavulcânicas de composição basaltica a riolítica, com grande quantidade de termos andesíticos e dacíticos. São comuns texturas e estruturas vulcânicas e piroclásticas preservadas. As rochas metassedimentares associadas são metagrauvacas, quartzitos finos e metacherts.

Mais a leste, na região de Iporá, as seqüências vulcanossedimentares de Jaupaci, Iporá e Amorinópolis são aparentemente pobres em termos vulcânicos intermediários, constituindo associações com caráter bimodal. Rochas dessas seqüências compreendem metabasaltos vesiculares ou porfiríticos e metariólitos que comumente mostram texturas piroclásticas. Rochas metassedimentares detríticas são praticamente ausentes na seqüência de Jaupaci (Amaro 1989) e constituem um pacote pouco importante na seqüência de Iporá, sendo representadas por granada micaxistos e metaconglomerado. Outras áreas isoladas e restritas de ocorrências de rochas metavulcânicas são conhecidas em toda região, especialmente nas de Bacilândia, Piloândia e Fazenda Nova.

A principal feição estrutural das rochas supracrustais da região é a foliação milonítica vertical de direção NS-NNW que oblitera, na maior parte dos casos, estruturas deformacionais anteriores. Lineações de estiramento e indicadores cinemáticos associados a essa foliação indicam movimentos direcionais dextrais (Amaro 1989).

Dados geocronológicos relativos às rochas metavulcânicas no sudoeste de Goiás indicam idades neoproterozóicas (Tabela 3). As idades de metamorfismo dessas rochas são reveladas pelos dados $\mathrm{U}-\mathrm{Pb}$ em titanita e Rb-Sr de rochas miloníticas e ficam entre 594 e 637 Ma. Metabasaltos e metariólitos dessas seqüências mostram características 


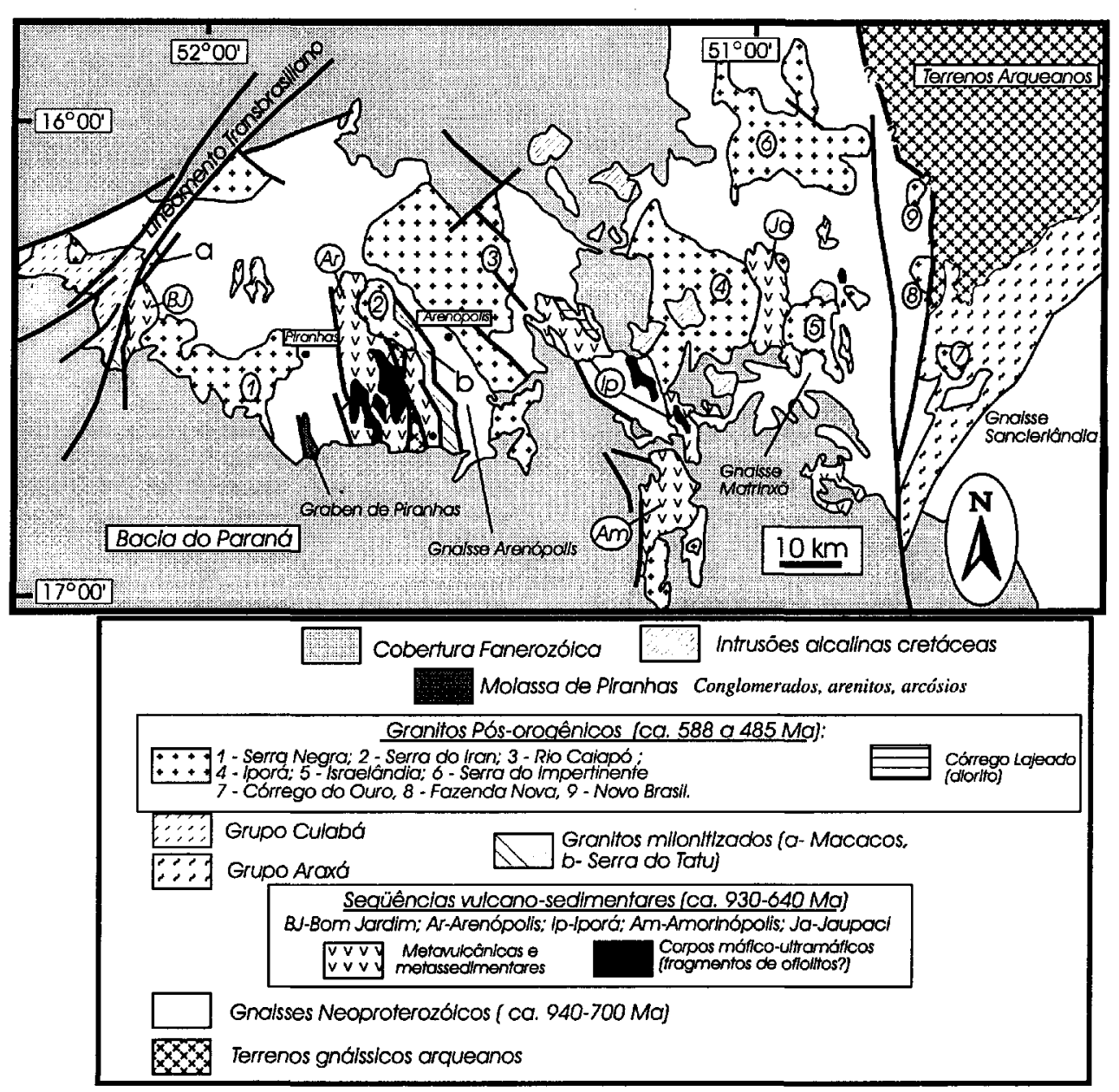

Figura 2 - Mapa geológico do Arco Magmatico de Goiás na região sudoeste de Goiás.

isotópicas e geoquímicas semelhantes às geradas em arcos vulcânicos modernos. As rochas anfibolíticas têm semelhanças com basaltos toleiíticos de baixo-K, característicos de arcos insulares pouco evoluídos, e as rochas félsicas mostram valores de $\mathrm{T}_{\mathrm{DM}}$ menores que $1.2 \mathrm{Ga}$, com $\varepsilon_{\mathrm{Nd}}(\mathrm{T})$ positivos (Pimentel \& Fuck 1992a,b).

Granitóides Tardi- a Pós-Orogenéticos Após o último evento de deformação e metamorfismo que afetou as rochas vulcânicas e granitóides do Arco Magmatico de Goiás, ocorreu um importante evento magmático caracterizado pelo alojamento de extensos corpos graníticos potássicos e intrusões gabro-dioríticas menores (Pimentel et al. 1996). Os corpos mais importantes são, de leste para oeste (Fig. 2), os granitos Serra Negra (ou Piranhas), Serra do Iran, Caiapó, Iporá, Israelândia, Serra do Impertinente, Córrego do Ouro, Fazenda Nova e Novo Brasil. Na maior parte dos casos, as intrusões graníticas são constituídas por granitos eqüigranulares não deformados que cortam a trama estrutural das rochas encaixantes. A exceção é o Granito Caiapó que mostra, em muitas localidades, uma fraca foliação NS e é tipicamente porfirítico. Diques de microgranito potássico não deformados também ocorrem em diversas localidades no oeste de Goiás. $\mathrm{Na}$ região da seqüência vulcanossedimentar de Arenópolis, esses diques formam um pequeno enxame cortando as rochas vulcanossedimentares, e o Granito Serra do Tatu. Esses diques mostram feições tais como esferulitos e cristais esqueletais de K-feldspato, indicativas de resfriamento rápido e intrusão a níveis crustais rasos. Elas provavelmente cristalizaram-se nos condutos que alimentaram derrames riolíticos/ignimbríticos pós-tectônicos, os quais foram posteriormente removidos pela erosão durante soerguimento pós-orogenético da região (Pimentel et al 1996). Outros granitos, como Serra Negra e Iporá, também mostram feições de cristalização em níveis crustais rasos. As intrusões são constituídas de biotita granitos e, menos comumente, de hornblenda granitos. Pequenos corpos gabróicos e dioríticos são encontrados no interior das intrusões graníticas, revelando o caráter bimodal do magmatismo. Estruturas indicando interação e mistura entre líquidos máficos e félsicos são encontradas localmente, especial-
Tabela 2 - Dados geocronológicos e isotópicos dos granitos milonitizados do sudoeste de Goiás.

\begin{tabular}{|c|c|c|c|c|c|}
\hline UNIDADE & $\begin{array}{c}\text { IDADE } \\
\text { (Ma) }\end{array}$ & ${ }^{71} \mathrm{Sr} /{ }^{36} \mathrm{Sr}$ inicial & $T_{D M}(G a)$ & $\mathcal{E}_{N d}(T)$ & Reler \\
\hline Granilo gnaisse - regiăo de Santa Fe & $467 \pm 10^{\circ}$ & 0,705 & & & 1 \\
\hline Granito Serra do Tatu & $692 \pm 110^{4}$ & 0,7062 & & & 2 \\
\hline $\begin{array}{l}\text { Granito porfirfictico da sequiênciána } \\
\text { vulcano-sedimentar de Jaupaci }\end{array}$ & $643 \pm 19^{*}$ & 0,7032 & 0,95 & $+3,21+3,5$ & 3 \\
\hline
\end{tabular}

mente junto aos contatos entre os granitos e os gabros e dioritos.Gabros e dioritos também ocorrem em intrusões individuais maiores, tais como o Complexo Córrego Lajeado (Fig. 4). Isócronas Rb-Sr para essas intrusões indicam idades que sugerem dois eventos intrusivos distintos: o mais velho entre ca. 588 e $560 \mathrm{Ma}$ e o mais jovem entre 508 e 485 Ma atrás (Tabela 4) (para uma revisão, ver Pimentel et al. 1996). Os granitos mais antigos revelam características petrográficas e geoquímicas semelhantes às dos granitóides do tipo-I diferenciados, enquanto que os mais jovens são mais alcalinos, similares a granitos tipo-A (Pimentel et al. 1996). As razões ${ }^{87} \mathrm{Sr} /{ }^{86} \mathrm{Sr}$ iniciais variam entre 0,703 e 0,710 e os valores de $\varepsilon_{\mathrm{Nd}}(\mathrm{T})$ entre $-4,0$ e $+3,0$. As composições isotópicas iniciais de $\mathrm{Nd}$ e $\mathrm{Sr}$ dos dois grupos de rochas graníticas sugerem que ambos são produto de refusão de fontes crustais isotopicamente semelhantes aos metatonalitos/granodioritos e metavulcânicas do arco (Pimentel et al. 1996). Os dois eventos são de natureza bimodal e interpretados como relacionados à extensão associada a soerguimento e denudação regional, após o Ciclo Brasiliano. A intrusão do complexo máfico-ultramáfico acamadado de Americano do Brasil provavelmente representa as manifestações mais precoces desse magmatismo (isócrona Sm-Nd com $612 \pm 66 \mathrm{Ma} ; \varepsilon_{\mathrm{Nd}}(\mathrm{T})=+3,1$ ) (Gioia 1997, Nilson et al. 1997).

O Arco Magmático da região sudoeste de Goiás representa, portanto, uma vasta área de crosta continental juvenil neoproterozóica, interpretada como o resultado da amalgamação de suítes de arcos magmáticos edifícados entre ca. 900 e 640 Ma atrás. Alguns fragmen- 

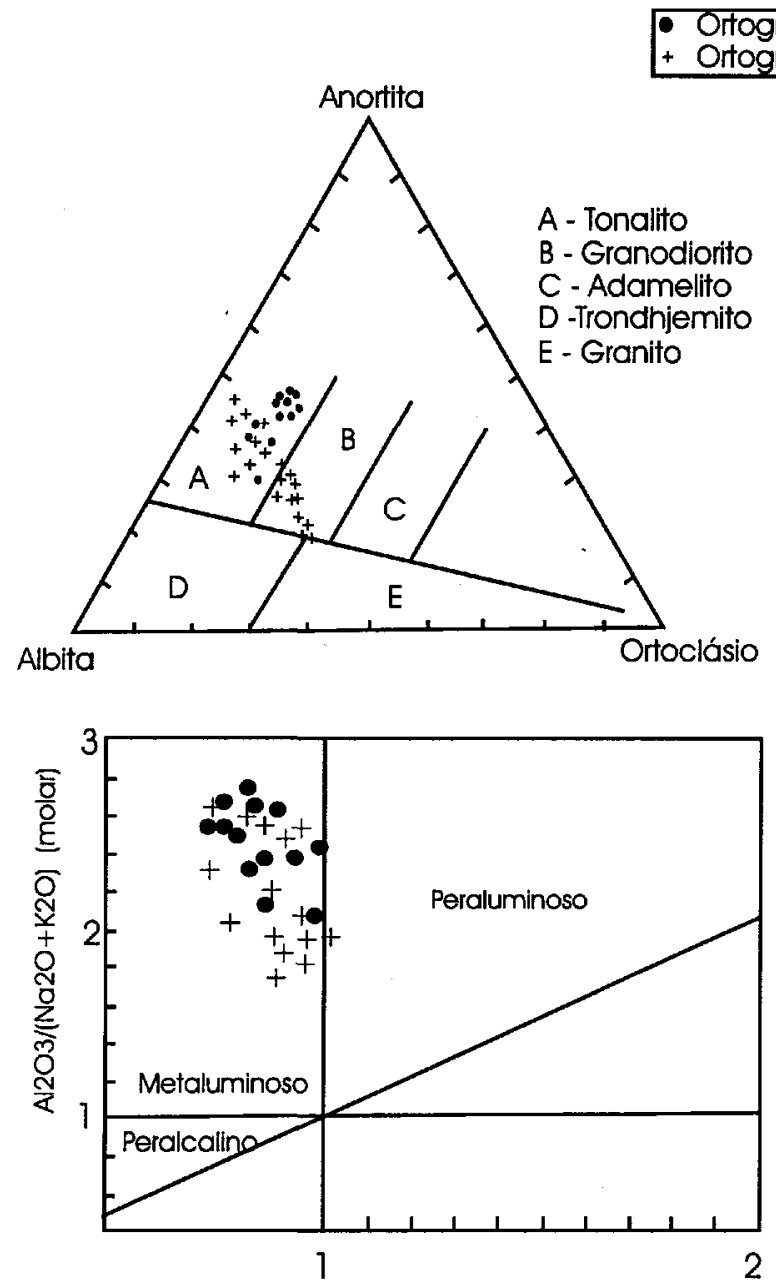

$\mathrm{Al} 2 \mathrm{O} 3 /(\mathrm{CaO}+\mathrm{Na} 2 \mathrm{O}+\mathrm{K} 2 \mathrm{O})$ (molar)
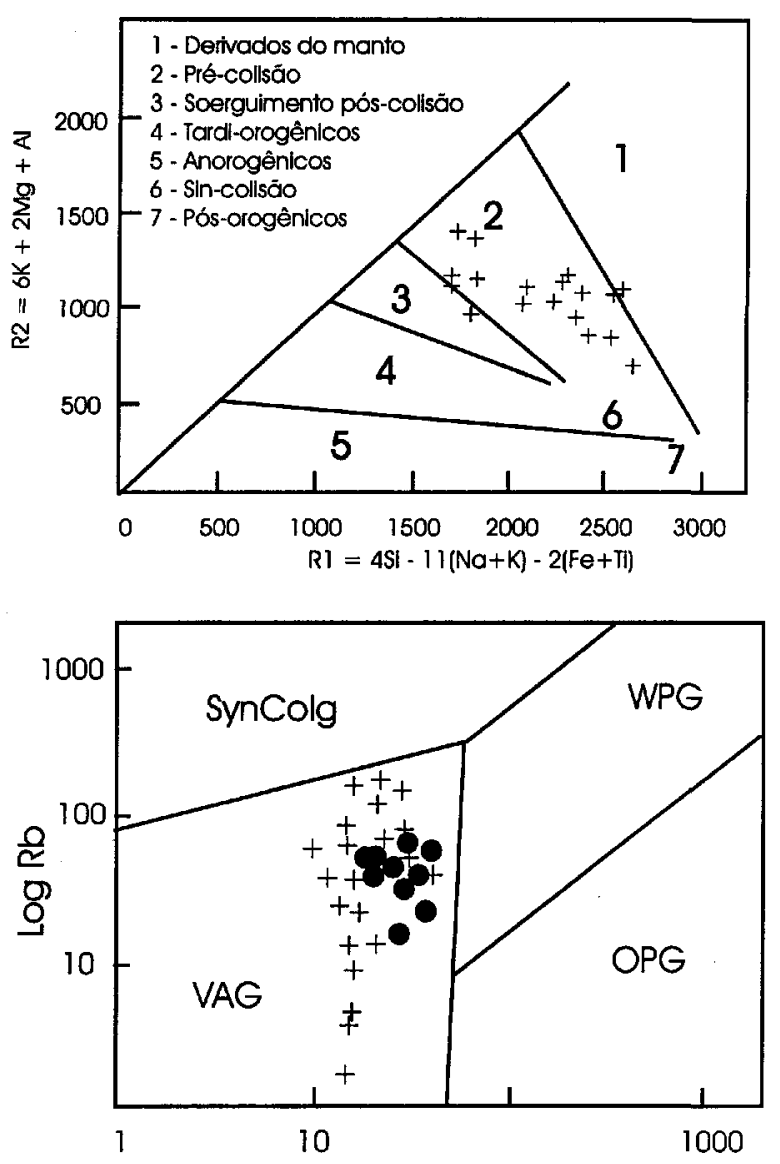

100

$\log (\mathrm{Y}+\mathrm{Nb})$

Figura 3 - Características geoquímicas de ortognaisses tonaliticos/granodioríticos do Arco Magmático de Goiás (dados de Pimentel \& Fuck 1992 b e Viana et al. 1995).

tos de crosta continental mais antiga, entretanto, ocorrem em meio às rochas jovens do arco, como o gnaisse Ribeirão que tem idades $\mathrm{Rb}-\mathrm{Sr}$ $\mathrm{e} \mathrm{Pb}-\mathrm{Pb}$ paleoproterozóicas e idades modelo $\mathrm{T}_{\mathrm{DM}}$ arqueanas (Pimentel 1992).

PROCEDIMENTOS ANALÍTICOS As análises isotópicas pelos métodos $\mathrm{Rb}$-Sr e Sm-Nd foram realizadas no Laboratório de Geocronologia da Universidade de Brasília.

Sr foi separado de amostras de rocha total usando procedimentos convencionais de separação em colunas de troca iônica. As amostras de $\mathrm{Sr}$ foram depositadas em arranjos de filamentos duplos de $\mathrm{Re}$ e as análises isotópicas realizadas em um espectrômetro de massa Finnigan MAT-262 multicoletor, em modo estático. Correções para o fracionamento de massa foram efetuados usando o valor de 8.375 para a razão ${ }^{88} \mathrm{Sr} /{ }^{86} \mathrm{Sr}$. Incertezas $2 \mathrm{a}$ nas razões ${ }^{87} \mathrm{Sr} /{ }^{86} \mathrm{Sr}$ medidas foram melhores do que $0,01 \%$.

A dissolução das amostras tem sido realizada em cápsulas Savillex seladas. Dois ataques iniciais com $\mathrm{HF}-\mathrm{HNO}_{3}$ concentrados são seguidos por ataque com $\mathrm{HC} 16 \mathrm{~N}$.

A extração de $\mathrm{Sm}$ e $\mathrm{Nd}$ a partir de amostras de rocha total seguiram as técnicas convencionais de troca iônica na qual a separação do grupo dos elementos lantanídeos em colunas de troca catiônica é seguida de cromatografía de fase reversa para a separacão de Sm e Nd com o uso de colunas contendo HDEHP (di-2-ethyl-hexil phosphoric acid) suportado em pó de teflon PTFE. No laboratório de geocronologia da UnB também tem sido usada a resina Ln-Spec para essa etapa. Uma solução traçadora mista de ${ }^{149} \mathrm{Sm}^{150} \mathrm{Nd}$ foi utilizada. As amostras de Sm e Nd foram depositadas em arranjos de filamentos duplos de Re e as análises isotópicas efetuadas em modo estático. Incertezas na determinação das razões $\mathrm{Sm} / \mathrm{Nd}$ e ${ }^{143} \mathrm{Nd} /{ }^{144} \mathrm{Nd}$ são consideradas melhores que $\pm 0.05 \%(1 \sigma)$ e $\pm 0,000005(1 \sigma)$ respectivamente, baseado em repetidas análises de padrões internacionais de rocha BCR-1 e BHVO-
1. As razões ${ }^{143} \mathrm{Nd} /{ }^{144} \mathrm{Nd}$ foram normalizadas para um valor de 0,7219 para a razão ${ }^{146} \mathrm{Nd} /{ }^{144} \mathrm{Nd}$. Brancos totais de Nd para todo o procedimento foram inferiores a 100pg.

RESULTADOS E DISCUSSÃO Região da Seqüência Vulcanossedimentar de Iporá As unidades geológicas précambrianas expostas nas vizinhanças de Iporá (Fig. 4) são: (i) sequiência vulcanossedimentar de Iporá, (ii) ortognaisses/granitos milonitizados, e (iii) intrusões gabro-dioríticas e graníticas tardi- a pós-tectônicas. A seqüência vulcanossedimentar de Iporá pode ser subdividida em (Franco et al. 1994): (i) Unidade Metamáfica, composta por anfibolitos e epidoto-clorita xistos, extremamente finos, composicionalmente correspondendo a basaltos e, mais raramente, a andesitos; (ii) Unidade Metafélsica, composta por rochas metavulcânicas félsicas, com poucas intercalações de metavulcânicas básicas. Apresentam textura porfirítica reliquiar, com fenocristais de plagioclásio, quartzo e feldspato potássico. Composicionalmente correspondem a riodacitos e riólitos (Franco et al. 1994). Rochas metassedimentares associadas a essas unidades são predominantemente metapelítos, localmente com granada. Metaconglomerados e quartzitos são subordinados.

A unidade de ortognaisses é constituída principalmente por gnaisses porfíroclásticos e gnaisses bandados, apresentando variados graus de milonitização. Feições ígneas reliquiares tais como textura porfirítica ou microporfirítica são observadas localmente (Rodrigues 1996). São comuns enclaves máficos microgranulares estirados, com formas lenticulares e bordas parcialmente consumidas.

Os ortognaisses correspondem predominantemente a granitos e granodioritos cálcio-alcalinos de alto potássio, com fácies tonalíticas muito restritas (Fig. 5). As características geoquímicas gerais dessas rochas sugerem que seus protólitos eram mais diferenciados que os de outros ortognaisses do sudoeste de Goiás, apresentando teores mais elevados de $\mathrm{SiO}_{2}$ e álcalis total (Fig. 5). Mostram característica metalu- 


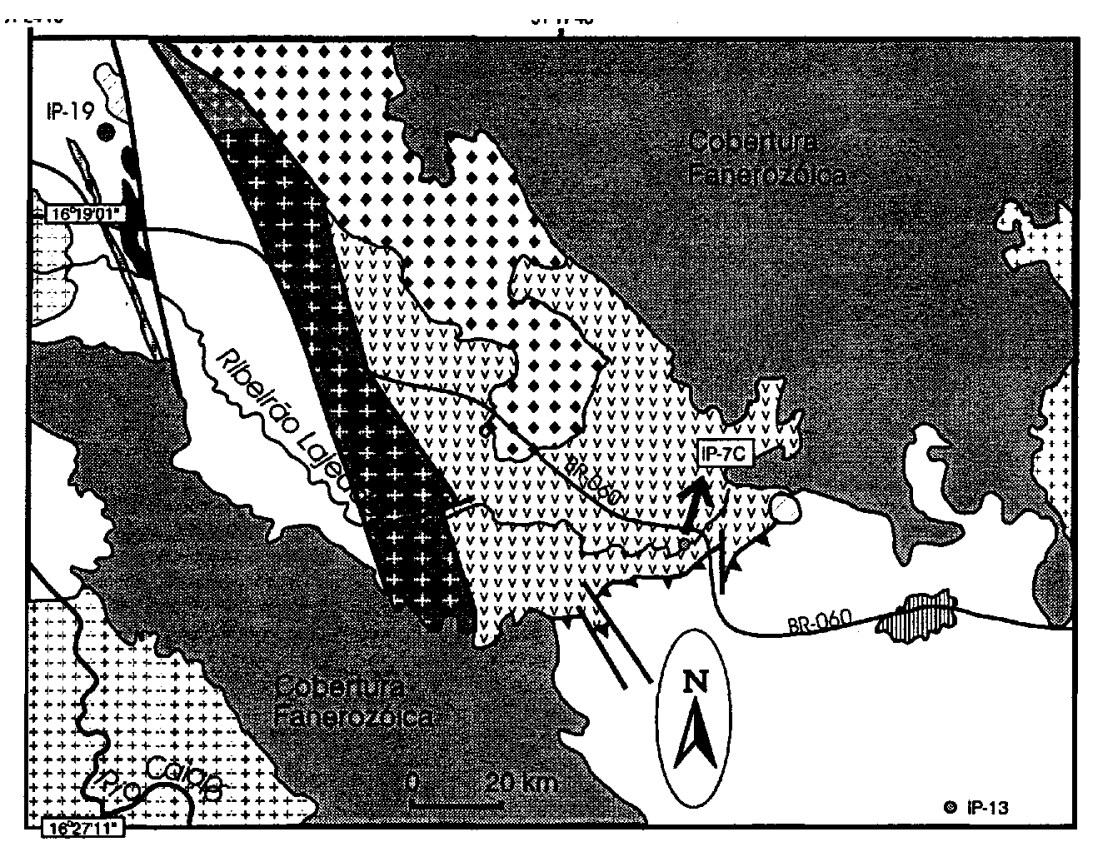

\begin{tabular}{|c|c|}
\hline & LEGENDA \\
\hline & Cobertura Fanerozbica \\
\hline & Granito Iporá \\
\hline & Granito Cajapó \\
\hline & $\begin{array}{l}\text { Complexo } \\
\text { Córrego Lajeado }\end{array}$ \\
\hline & Rochas ultramáficas \\
\hline & $\begin{array}{l}\text { Sequiência de iporá } \\
\text { Metadacitos, metarriolitos, } \\
\text { Hematita-muscovita xistos }\end{array}$ \\
\hline & Granitos miloniticos \\
\hline & Granito porfirítico \\
\hline & Milonitos, ultramilonitos \\
\hline & $\begin{array}{l}\text { Motagabros e } \\
\text { metapiroxenitos }\end{array}$ \\
\hline & $\begin{array}{l}\text { Ortognaisses granodioritico } \\
\text { e tonaliticos }\end{array}$ \\
\hline
\end{tabular}

Figura 4 - Mapa geológico da seqüencia vulcanossedimentar de Iporá, sudoeste de Goiás.
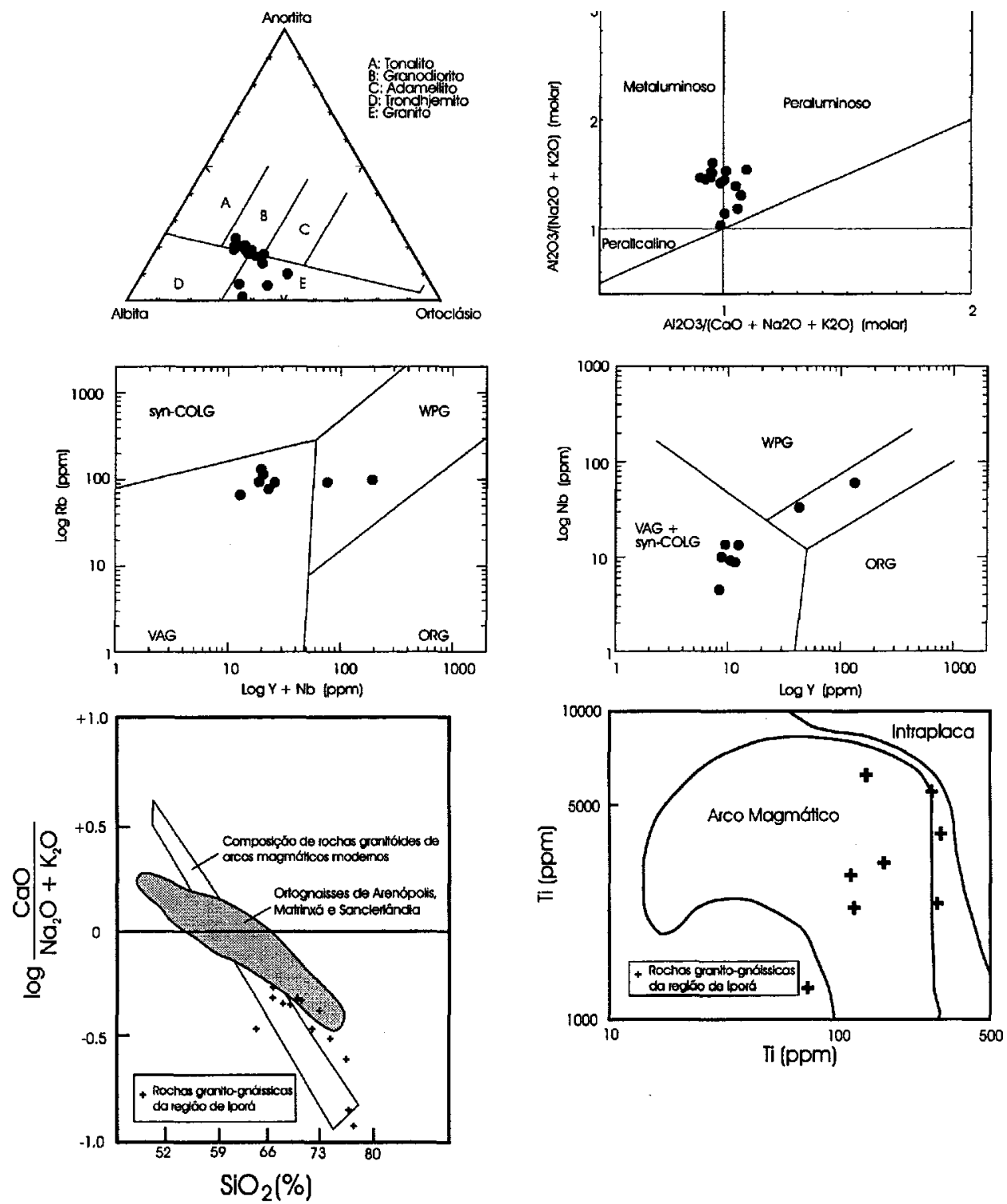

Figura 5 - Características geoquímicas dos ortognaisses vizinhos à seqüencia vulcanossedimentar de Iporá. 
Tabela 3 - Dados geocronológicos e isotópicos para rochas metavulcânicas do Arco Magmático de Goiás na região sudoeste do Estado.

\begin{tabular}{|c|c|c|c|c|c|}
\hline UNIDADE & $\begin{array}{c}\text { IDADE } \\
(\mathrm{Ma})\end{array}$ & "Sr ${ }^{2 / 4}$ Sr inicial & $T_{D M}(\mathrm{Ga})$ & $\varepsilon_{\mathrm{end}}(\mathrm{T})$ & Refer. \\
\hline Metarriolito - Sequéncia de Arenópolis & $\begin{array}{c}929 \pm 8^{\circ} \\
933 \pm 60^{\circ} \\
594^{\circ}\end{array}$ & 0,7035 & $0.9 \cdot 1.2$ & $+2,51+5,8$ & 1 \\
\hline Anfibolito - Sequéncia de Arenópolis & $859 \pm 43^{d}$ & & & & 3 \\
\hline Metarriolito milonflico - Fazenda Nova & $600 \pm 31^{6}$ & 0,7036 & $0,9 \cdot 1,1$ & $+0,21+2,4$ & 2 \\
\hline Metarriolito - Seqüencia de Jaupaci & $\begin{array}{l}764 \pm 14^{2} \\
594 \pm 37^{b}\end{array}$ & 0,7052 & 0 & $+3,8+4,7$ & 1,2 \\
\hline
\end{tabular}

Tabela 4 - Súmula de dados geocronológicos e isotópicos relativos aos corpos graniticos, dioríticos e máfico-ultramáficos tardi- a pósorogenéticos no sudoeste de Goiás.

\begin{tabular}{|c|c|c|c|}
\hline Unidade & Ldade $\left(M_{a}\right)$ & Razzo lsoóónica Inicjal & Referencia \\
\hline $\begin{array}{l}\text { Complexo Máfico-Uluramáfico } \\
\text { de Ammericano do Brasil }\end{array}$ & $612 \pm 66^{4}$ & $t_{\mathrm{N}}(\mathrm{T})=+3,1$ & 1 \\
\hline Complexo Gabro-Diorlico Gongoms & $615 \pm 108^{6}$ & 0,7154 & 2 \\
\hline Diorito Serra do Iran & $-622^{\circ}$ & 0.7039 & 3 \\
\hline Complexo Gabro-Diortico Lajeado & $\sim 651^{\circ}$ & 0,7029 & 4 \\
\hline Granito Serta do Iran & $588 \pm 19^{b}$ & 0,2044 & $\mathbf{3}$ \\
\hline $\begin{array}{l}\text { Granito Serra do Impertinente (fícies } \\
\text { porfirftica) }\end{array}$ & $576 \pm 18^{6}$ & 0,7032 & 3 \\
\hline $\begin{array}{l}\text { Granito Serra do Impertinente } \\
\text { (fácies equigranular) }\end{array}$ & $485 \pm 18^{b}$ & 0,7067 & 3 \\
\hline Granito Istraclândia & $\begin{array}{l}554 \pm 20^{\circ} \\
579 \pm 3^{\circ}\end{array}$ & 0,7045 & $\begin{array}{l}3 \\
5\end{array}$ \\
\hline Dique de Microgranito & $564 \pm 15^{b}$ & 0,7094 & 3 \\
\hline Granito Serra Negra & $508 \pm 24^{b}$ & 0,7057 & 3 \\
\hline & $490 \pm 24^{\circ}$ & 0,7057 & 3 \\
\hline
\end{tabular}

Tabela 5 - Dados isotópicos Rb-Sr para amostras de rocha total de granitóides da região de Iporá

\begin{tabular}{|c|c|c|c|c|}
\hline Amostra & Rb(ppm) & Sr(ppm) & ${ }^{87} \mathrm{Rb}^{86} \mathrm{Sr}$ & ${ }^{77} \mathrm{Sr}^{86} \mathrm{Sr}$ \\
\hline IP-19A & 101 & 515 & 0,568 & 0,71021 \\
\hline IP-19D & 59 & 554 & 0,308 & 0,70741 \\
\hline IP-19E & 66 & 698 & 0,274 & 0,70758 \\
\hline IP-19F & 56 & 516 & 0,317 & 0,70762 \\
\hline IP-19H & 63 & 471 & 0,387 & 0,70837 \\
\hline IP-19I & 56 & 516 & 0,314 & 0,70779 \\
\hline IP-19L & 63 & 565 & 0,323 & 0,70805 \\
\hline IP-13B & 124 & 839 & 0,428 & 0,70944 \\
\hline IP-13D & 70 & 677 & 0,299 & 0,70704 \\
\hline IP-13E & 95 & 391 & 0,703 & 0,71134 \\
\hline
\end{tabular}

Tabela 6 - Dados isoíópicos Sm-Nd em rocha total de amostras de ortognaisses da região de Iporá, Fazenda Nova e Firminópolis.

\begin{tabular}{|c|c|c|c|c|c|}
\hline Amostra & Sm(ppm) & Nd(ppm) & ${ }^{10} \mathrm{Sm}^{1 / 14} \mathrm{Nd}$ & ${ }^{143} \mathrm{Nd}^{144} \mathrm{Nd}$ & $\mathrm{T}_{\mathrm{DM}}(\mathrm{Ga})$ \\
\hline IP-7C & 4,713 & 22,34 & 0,128 & 0,512622 & 0,77 \\
\hline IP-7D & 7,330 & 38,93 & 0,114 & 0,512388 & 1,01 \\
\hline IP-11 & 10,44 & 62,84 & 0,100 & 0,512212 & 1,12 \\
\hline IP-13A & 4,058 & 22,76 & 0,108 & 0,512265 & 1,13 \\
\hline IP-19A & 2,520 & 16,71 & 0,091 & 0,512183 & 1,08 \\
\hline IP-33F & 8,083 & 47,95 & 0,102 & 0,512307 & 1,01 \\
\hline FIRIA & 4,340 & 34,60 & 0,076 & 0,512054 & 1,10 \\
\hline FIRIB & 5,923 & 32,40 & 0,110 & 0,512166 & 1,30 \\
\hline FIRIC & 3,860 & 18,19 & 0,128 & 0,512315 & 1,32 \\
\hline FIRIE & 3,557 & 17,95 & 0,112 & 0,512199 & 1,38 \\
\hline FIRIF & 3,460 & 17,13 & 0,122 & 0,512207 & 1,40 \\
\hline FIRIG & 5,400 & 29,80 & 0,110 & 0,512219 & $1,2 !$ \\
\hline MI-1 & 5,010 & 29,48 & 0,103 & 0,511316 & 2,42 \\
\hline MI-2 & 5,166 & 28,59 & 0,109 & 0,511801 & 1,83 \\
\hline MI-3 & 7,050 & 36,70 & 0,116 & 0,511848 & 1,89 \\
\hline MI-4 & 3,156 & 18,43 & 0,104 & 0,510764 & 3,27 \\
\hline MI-5 & 3,897 & 22,39 & 0,105 & 0,512294 & 1,06 \\
\hline MI-6 & 10,10 & 34,91 & 0,111 & 0,511893 & 1,73 \\
\hline BCD-201 & 0,564 & 2,575 & 0,132 & 0,512547 & 0,95 \\
\hline BCD-155 & 7,143 & 33,37 & 0,129 & 0,512566 & 0,88 \\
\hline
\end{tabular}
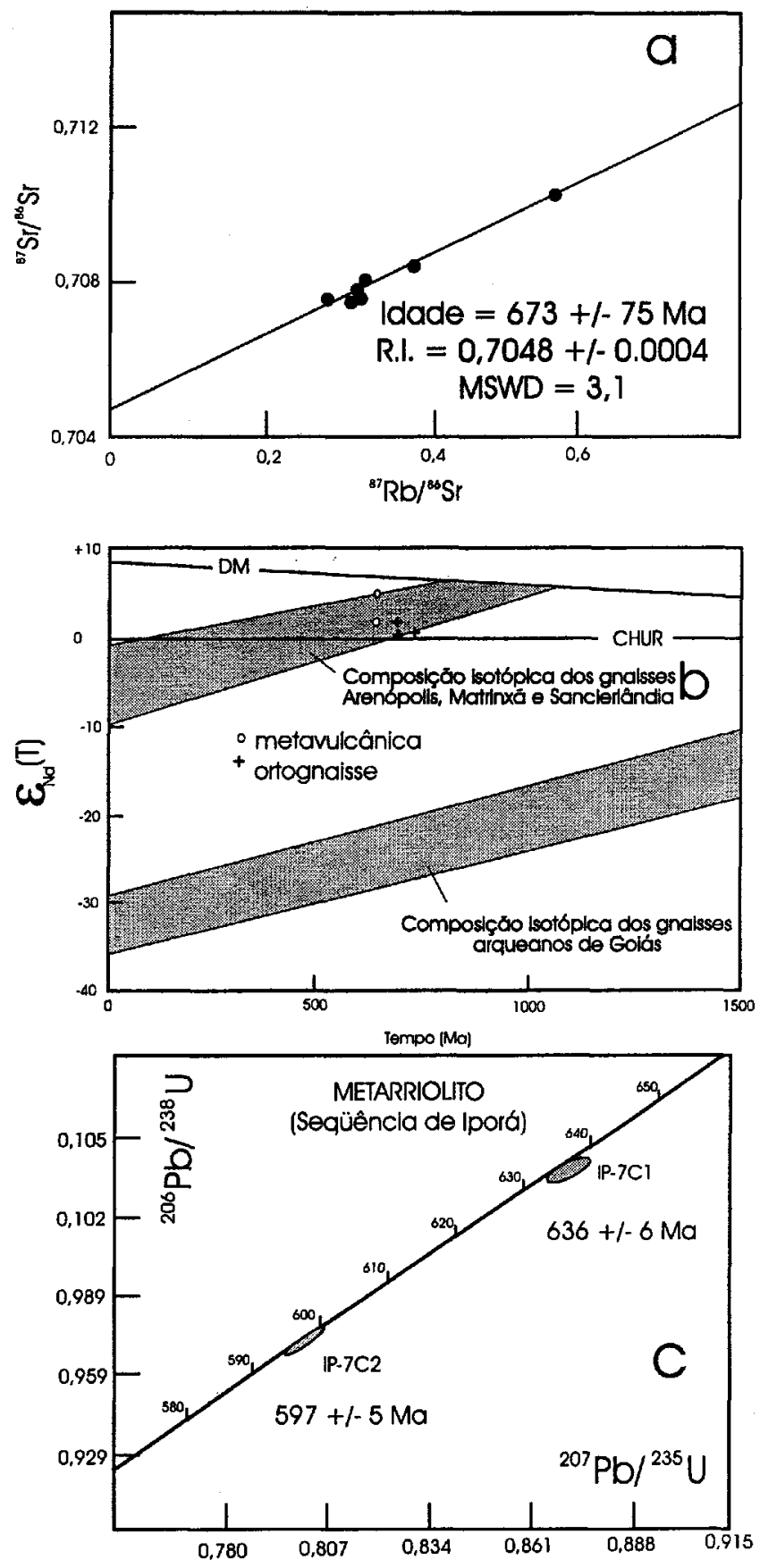

Figura 6 - Dados geocronológicos e isotópicos para rochas do Arco Magmático de Goiás na região de Iporá: (a) Isócrona $\mathrm{Rb}-\mathrm{Sr}$ dos ortognaisses, (b) composição isotópica de Ndpara rochas metaígneas, (c) diagrama da concórdia para rocha metavulcânica da seqüência vulcanossedimentar de Iporá.

Tabela 7 - Dados isotópicos U-Pb para zircões da rocha metavulcânica da Seqüência de Iporá.

\begin{tabular}{|c|c|c|c|c|c|c|c|c|}
\hline Amostra & $\begin{array}{l}\text { Peso } \\
\text { (mg) }\end{array}$ & $\begin{array}{c}U \\
\text { (ppm) }\end{array}$ & $\begin{array}{c}\text { Pb radiog } \\
\text { (ppm) }\end{array}$ & $\begin{array}{c}\text { Pb commum } \\
\text { total }(\mathrm{pg})\end{array}$ & ${ }^{206} \mathrm{~Pb} \mathrm{P}^{304} \mathrm{~Pb}$ & ${ }^{2006 \mathrm{pb}} \mathrm{p}^{224} \mathrm{U}$ & ${ }^{2010} \mathrm{~Pb} \mathrm{p}^{235} \mathrm{U}$ & ${ }^{207} \mathrm{~Pb} /{ }^{206} \mathrm{~Pb}$ \\
\hline [P-7Cl & 0,014 & 363 & 37,0 & 22 & 1504 & 0,1035 & 0,8718 & 0,0611 \\
\hline $\mathrm{IP}-7 \mathrm{CC}$ & 0,04 & 441 & 40,1 & 51 & 2121 & 0,0970 & 0,8016 & 0.0599 \\
\hline
\end{tabular}




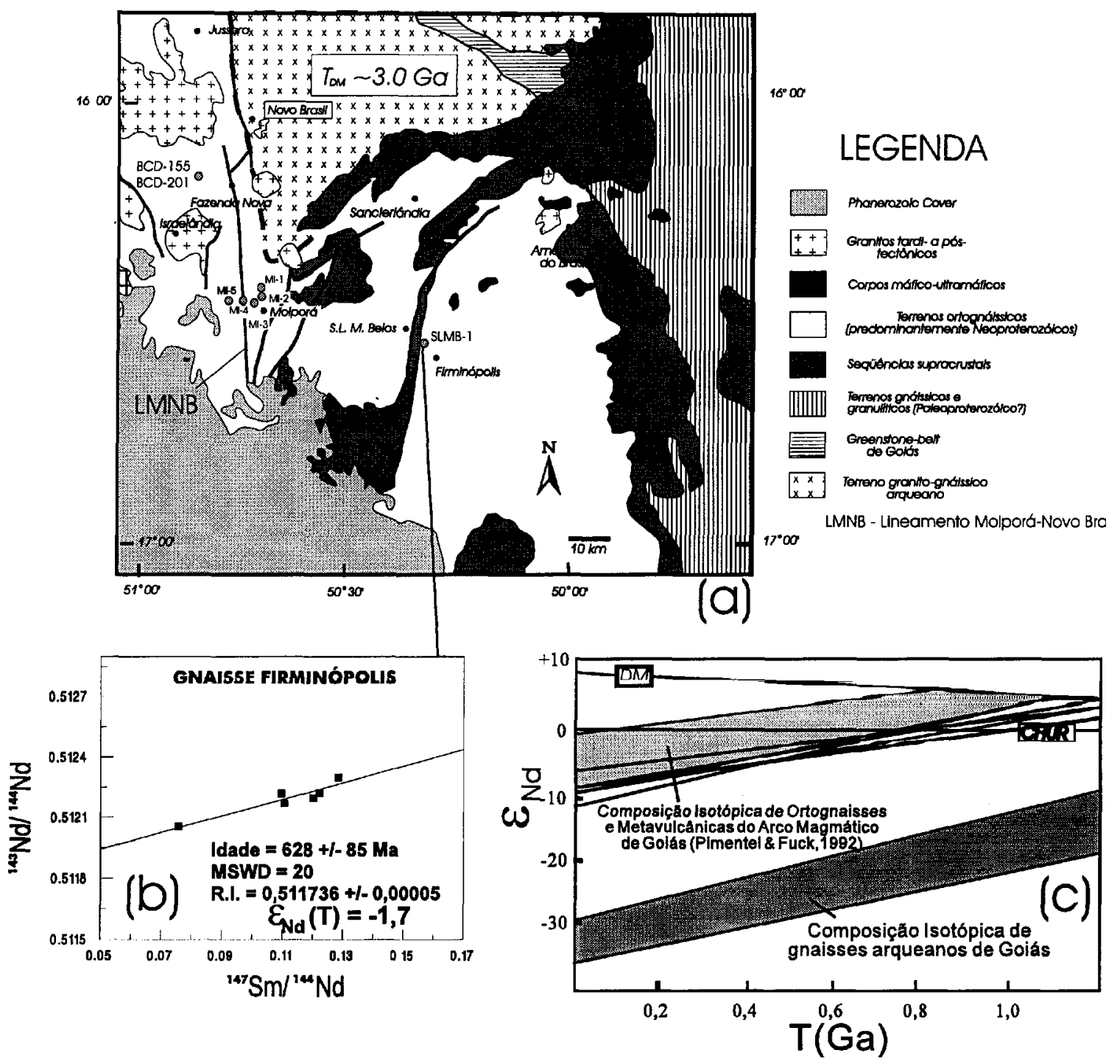

Figura 7 - Esboço geológico da região de Moiporá-Firminópolis (a) e resultados geocronológicos/isotópicos dos gnaisses Firminópolis (b e c)

minosa a fracamente peraluminosa, com uma tendência mais peraluminosa se comparado com os ortognaisses de ca. 900 Ma das regiões de Arenópolis, Matrinxã e Sanclerlândia (Fig. 5). Os conteúdos de elementos traço desses ortognaisses revelam composições semelhantes às de granitos de arco vulcânico, de acordo com a classificação de Pearceef a/. (1984) (Fig. 5).

O contato entre os ortognaisses e a seqüência vulcanossedimentar de Iporá são faixas de transcorrência ou cavalgamento, dificultando o estabelecimento das relações estratigráficas entre as duas unidades. Sugere-se que os ortognaisses sejam mais antigos que as supracrustais, com base na presença de diques de rochas metabásicas nos gnaisses e que apresentam composição química muito semelhante aos anfibolitos da seqüência vulcanossedimentar (Franco et al. 1994).

Os corpos Córrego Lajeado, Caiapó e Iporá, representantes do magmatismo bimodal tardi- a pós-orogenético, mostram clara relação de intrusão nas unidades metamórficas supracitadas. Os granitos Caiapó e Iporá têm Ådades isocrônicas Rb-Sr de $588 \pm 17$ Ma e $490 \pm$ $24 \mathrm{Ma}$, com razões ${ }^{87} \mathrm{Sr} /{ }^{86} \mathrm{Sr}$ iniciais de ca. 0,7058 e 0,7057 , respectivamente (Pimentel \& Fuck 1994), conforme resumido na Tabela 4.

Dados isotópicos $\mathrm{Rb}-\mathrm{Sr}$ foram obtidos em amostras de ortognaisses coletados em dois afloramentos distintos (mapa da Fig. 4; dados analíticos na Tabela 5). A isócrona $\mathrm{Rb}$-Sr construída com todas as amostras indica a idade de $673 \pm 75$ Ma e razão inicial de $0,7048 \pm$ $0,0004(\mathrm{MSWD}=3,1)$ (Fig. 6a). O valor relativamente baixo da razão inicial é indicativa de curta residência crustal dos protólitos. Dados isotópicos $\mathrm{Sm}-\mathrm{Nd}$ de quatro amostras revelaram idades modelo $\mathrm{T}_{\mathrm{DM}}$ entre 1,0 e $1,1 \mathrm{Ga}$ e $\varepsilon_{\mathrm{Nd}}(\mathrm{T})$ entre $+0,4$ e $+1,9$ (Tabela 6), valores esses compatíveis com os encontrados nos ortognaisses Arenópolis, Ma-

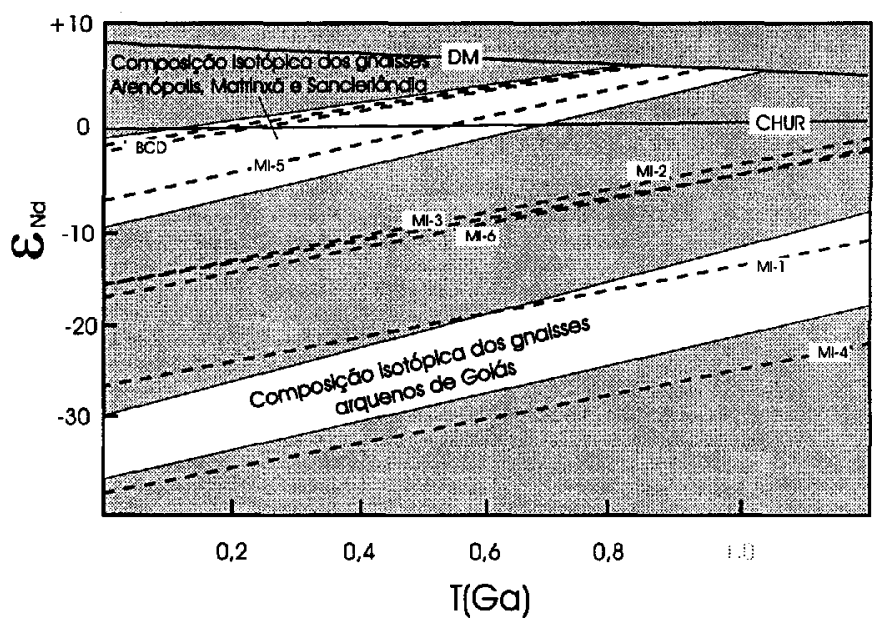

Figura 8 - Composição isotópica de Nd de gnaisses da região entre Fazenda Nova e Moiporá.

trinxã e Sanclerlândia, representantes do Arco Magmático de Goiás (Fig. 6b). Assim, muito embora sejam mais jovens e com características geoquímicas mais evoluídas, as composições isotópicas dessas rochas são semelhantes às de rochas juvenis do arco. Isto sugere que seus protólitos ou foram derivados diretamente do manto ou repre- 

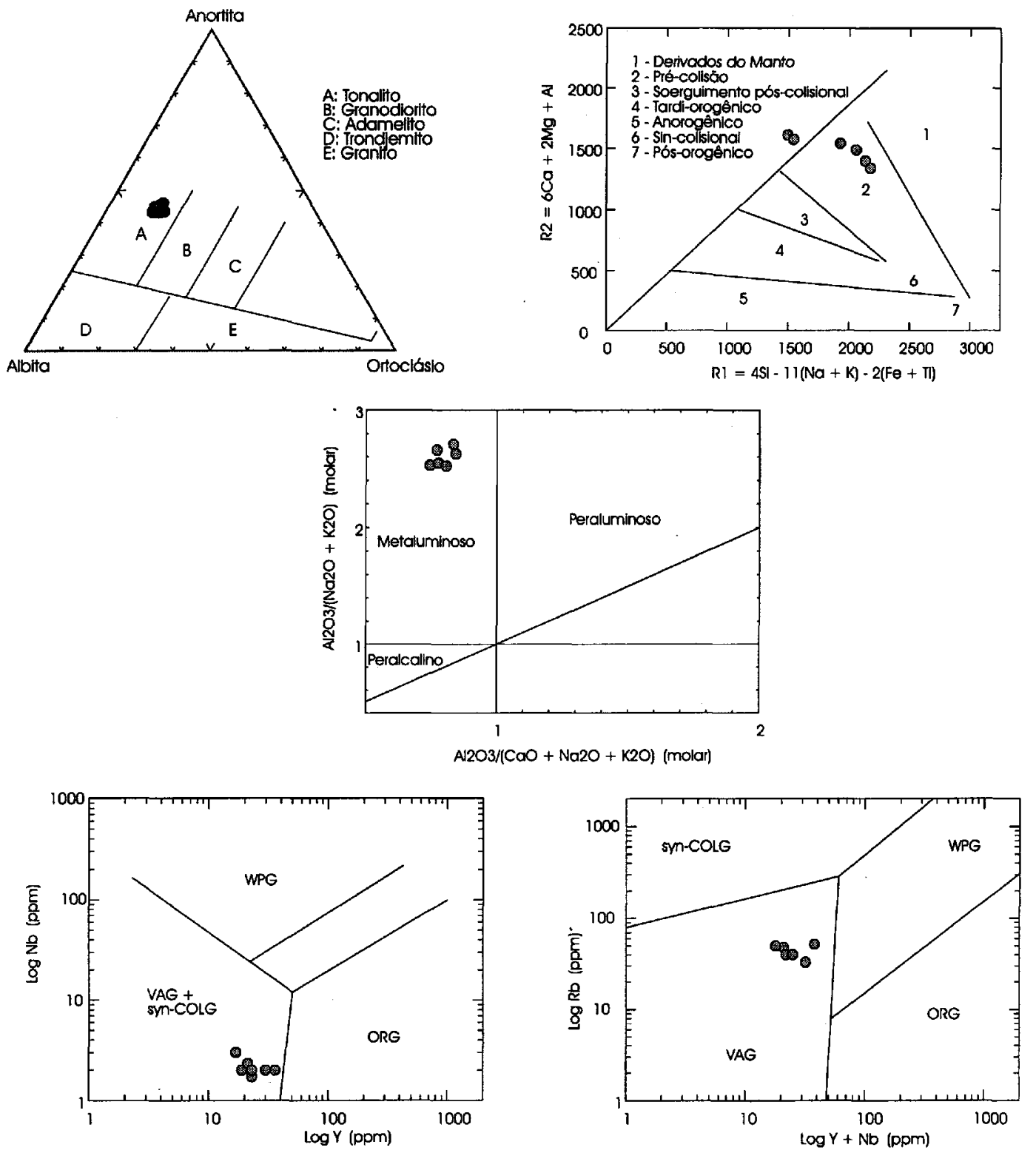

Figura 9 - características geoquímicas do gnaisse Firminópolis.

sentam os produtos de refusão e retrabalhamento de rochas do próprio Arco Magmático de Goiás.

Uma amostra de rocha metavulcânica félsica da seqüência de Iporá foi datada pelo do método U-Pb em zircões (Tabela 7). Duas populações de zircão distintas foram identificadas nessa amostra: (i) população IP-7C $\mathrm{C}_{1}$ é composta por cristais de prisma curto, pequenos $(100 \mu \mathrm{m})$, incolores e límpidos e (ii) população IP-7C2 composta por cristais maiores $(>200 \mu \mathrm{m})$ e ricos em inclusões incolores. Zircões IP-7C 1 são concordantes e mostram idade de $636 \pm 6 \mathrm{Ma}$, aqui interpretada como a melhor estimativa para a época de cristalização da rocha vulcânica original (Fig. 6c). A fração IP-7 $\mathrm{C}_{2}$ também é concordante, porém indica uma idade bem mais jovem, de $597 \pm 5 \mathrm{Ma}$. De difícil interpretação, essa idade mais jovem é aqui considerada como indicativa de um evento tectônico ou hidrotermal tardio, relacionado ao metamorfismo da seqüência vulcanossedimentar de Iporá. As análises $\mathrm{Sm}-\mathrm{Nd}$ em duas amostras dessa rochas metavulcânicas félsicas indicaram idades modelo $\mathrm{T}_{\mathrm{DM}}$ de 0.76 e $1.0 \mathrm{Ga}$, e $\varepsilon_{\mathrm{Nd}}(\mathrm{T}) \mathrm{de}+5.3$ e +1.8 , respectivamente (Tabela 6 , Fig. 6b).

Região de Fazenda Nova-Moiporá Na regi ao entre Fazenda Nova, Israelândia e Moiporá afloram diversas unidades de ortognaisses de idade desconhecida, além da seqüência vulcanossedimentar de Jaupaci (Fig. 7). Essa área é caracterizada pelo importante sistema de lineamentos Moiporá-Novo Brasil, provavelmente parte do sistema Transbrasiliano, que é representado no campo por milonitos e ultramilonitos com foliação vertical e lineações de estiramento horizon- tal. Dados geocronológicos anteriores indicam idades $\mathrm{U}-\mathrm{Pb}, \mathrm{Rb}-\mathrm{Sr}$ e $\mathrm{Sm}-\mathrm{Nd}$ neoproterozóicas para as rochas metavulcânicas da seqüência e milonitos associados ao lineamento Moiporá-Novo Brasil (Pimentel \& Fuck 1992). Aqui são reportadas algumas determinações Sm-Nd adicionais em rochas dessa área (Tabela 6).

As amostras BCD 201 e BCD 155 correspondem a um dacito pórfiro e tonalito, respectivamente, associados a uma pequena mineralização de Au entre as cidades de Fazenda Nova e Jaupaci (Fig. 7). Apesar de suas idades de cristalização permanecerem desconhecidas, os resultados isotópicos Sm-Nd indicam idades modelo jovens, de 0,95 $\mathrm{Ga}$ e $0,88 \mathrm{Ga}$, respectivamente, com composições isotópicas semelhantes às das rochas do Arco Magmático de Goiás, demonstrando que os protólitos das mesmas são juvenis e de idade neoproterozóica. O mesmo é indicado pela análise da amostra MI-5, um granito milonitizado exposto mais a sul, na região de Moiporá (Fig. 8).

Em contraste, as amostras MI- 2, MI-3, MI-4 e MI-6, correspondendo a biotita gnaisses finos e localmente bandados, expostos na extremidade sul do sistema de lineamentos Moiporá-Novo Brasil mostram composições isotópicas indicativas da presença de crosta siálica substancialmente mais antiga nessa região. Para essas amostras, as idades modelo $\mathrm{T}_{\mathrm{DM}}$ variam entre ca. 1,73 e 3,3 Ga (Tabela 6). Na figura 8 , a composição isotópica dessas rochas é comparada com a do gnaisse Ribeirão e outras rochas arqueanas de Goiás. Uma vez que as idades de cristalização dessas rochas ainda são desconhecidas, é impossível dizer se representam rochas neoproterozóicas contaminadas 
com crosta siálica mais velha (gnaisse Ribeirão, por exemplo), ou se elas próprias representam um pequeno fragmento exótico de crosta continental em meio às rochas juvenis do Arco Magmático de Goiás. De qualquer modo, a presença de material siálico mais antigo nessa região fica comprovada com base na investigação $\mathrm{Sm}-\mathrm{Nd}$.

Região de Firminópolis Mais a leste, na região entre São Luiz de Montes Belos e Firminópolis (Fig. 7), estão expostos hornblendabiotita gnaisses cinzentos, ricos em epidoto, e fortemente deformados, aqui denominados de gnaisse Firminópolis. Sua composição é tonalítica, metaluminòsa, com teores de elementos traço semelhantes a granitóides primitivos de arcos vulcânicos (Fig. 9). Petrográfíca e quimicamente essas rochas são bastante semelhantes aos gnaisses tonalíticos expostos na região de Sanclerlândia, a norte, cujos protólitos são neoproterozóicos (ca. $900 \mathrm{Ma}$ ). As idades modelo $\mathrm{T}_{\mathrm{DM}}$, entretanto, mostraram valores um pouco mais velhos (entre ca. 1,1 e 1,4 $\mathrm{Ga}$ ), se comparados com as dos outros ortognaisses da região, levantando a possibilidade de uma limitada contaminação do magma tonalítico original com crosta continental mais velha (Fig. 7c). As seis amostras formam um arranjo linear no diagrama isocrônico (MSWD de ca. 20) que indica a idade aproximada de $630 \mathrm{Ma}$ e $\varepsilon_{\mathrm{Nd}}(\mathrm{T})$ de -1.7 , provavelmente indicativa da época de metamorfismo (Fig. 7).

CONCLUSÕES Os dados geocronológicos, isotópicos e geoquímicos aqui reportados para ortognaisses e uma metavulcânica expostas entre Iporá e Firminópolis, no sudoeste de Goiás, revelam que:

- os protólitos das unidades estudadas são, em sua maioria, rochas ígneas cristalizadas a partir de magmas juvenis neoproterozóicos, integrantes, portanto, do Arco Magmático de Goiás.;

- a rocha metavulcânica félsica da seqüência vulcanossedimentar de Iporá representa o exemplar vulcânico mais jovem já datado no Arco Magmático. A idade Rb-Sr dos gnaisses adjacentes também indica idade relativamente jovem comparado com outras unidades gnáissicas na região. Geoquimicamente, os ortognaisses de Iporá são mais "evoluídos" que os gnaisses de Arenópolis, Matrinxã, Sanclerlândia e Firminópolis. Aparentemente, essa parte do Arco Magmático de Goiás é constituída por associações mais jovens e mais evoluídas, comparado com as de Arenópolis, Israelândia e Sanclerlândia. A interpretação desses dados é a de que a região do arco circunvizinha à cidade de Iporá é distinta das adjacentes a oeste e leste e é provável que essas rochas se formaram em um ambiente geotectônico diferente, talvez em presença de crosta continental mais velha. Os dados isotópicos de $\mathrm{Nd}$, entretanto, sugerem que as rochas granitóides e metavulcânicas de Iporá tenham se formado pelo retrabalhamento das rochas mais antigas do Arco Magmático, sem presença significativa de crosta continental muito mais antiga.

- os terrenos gnáissicos da região de Moiporá indicam a presença de um fragmento de crosta siálica mais antiga naquela área, provavelmente em uma situação tectônica semelhante à do gnaisse Ribeirão, na região de Arenópolis. Juntamente com o gnaisse Ribeirão, os gnaisses da região de Moiporá representam as únicas exposições, no Arco Magmático no sudoeste de Goiás, de rochas com assinaturas isotópicas de $\mathrm{Nd}$ indicativas da presença de material siálico antigo.

- os gnaisses de Firminópolis são integrantes do Arco Magmático de Goiás. Sua composição geoquímica é típica de tonalitos de arcos vulcânicos e a composição isotópica de $\mathrm{Nd}$, apesar de resultar em idades modelo um pouco mais velhas que o padrão geral das rochas juvenis da região, mostra que seus protólitos são comparáveis àqueles dos gnaisses Arenópolis, Matrinxã e Sanclerlândia.

Agradecimentos Os autores agradecem o apoio logístico fornecido pela empresa Santa Elina Mineração S.A. para realização de trabalhos de campo na região de Fazenda Nova e Moiporá. Também agradecem o apoio do CNPq pelo apoio financeiro e bolsas de pósgraduação e de pesquisa.

\section{Referências}

Amaro V.E. 1989. Geologia e petrologia da seqüencia metavulcânica de Jaupaci-GO e lineamentos associados. Dissertação de Mestrado. Universidade de Brasília, Brasília, 230 P-

Barbour A.P., Girardi V A V., Kawashila K. Souza A.M.S. 1979 Geologia do complexo máfico-ultramáfico alcalino de Santa Fé, Goiás. Boletim IG-USP, 10:11-18.

Brito Neves B.B. \& Cordani U.G. 1991. Tectonic evolution of South America during the late Prolerozoic. Precambrian Research, 53:23-40.

Correia C.T., Girardi V.A.V., Tassinari, C.C.G.; Jost, H. 1997. Rb-Sr and Sm-Nd gcochronology of the Cana Brava layered mafic-ultramafic intrusion, Brazil, and considerations regarding its tectonic evolution. Rev. Bras. Geoc.,27(2): 163-168.

Danni J.C.M. \& Campos J.E.G. 1994. Geologia e petrologia do Complexo Lajeado, Iporá, Goiás. In: SBG, IV Simpósio de Geologia do Centro-Oestc, Brasília, Boletim de Resumos Expandidos, 152-154

Drake Jr. A.A. 1980. The Serra de Caldas Window, Goiás. USGSProf. Paper, 1119(A/B):1-11

Ferreira Filho C.F., Kamos S., Fuck R.A., Krogh T.E., Naldrelt A.J. 1994. Zircon and rulile U-Pb geochronology of the Niquelândia layered mafic and ultramafic intrusion, Brazil constraints for the timing of magmalism and high grade metamorphism. Precamb. Res., 68:241-255.

Franco H.A., Campos J.E.G., Danni J.C.M. 1994. A seqüÊncia vulcanossedimentar de Iporá/Amorinópolis: uma contribuição. In: SBG XXXVIII Congresso Brasileiro de Geologia., Baln. Camboriú, Boletim de Resumos Expandidos, 108-109.

Fuck R.A., Jardim de Sá E.F., Pimentcl M.M., Dardenne M.A., Pedrosa Soares A.C. 1993. As faixas de dobramcntos marginais do Crálon do São Francisco: síntese dos conhecimentos In: J.M.L. Domingucz \& A. Misi (cds.) O Crálon do São Francisco, Salvador, SBG-SGM-CNPq, 161-185.

Fuck R.A., Pimentel M.M., Silva L.J.H.D. 1994. Compartimentação tectônica da porção oriental da Província Tocantins. In: SBG, XXXVIII Congresso Brasileiro de Geologia, Baln. Camboriú, Boletim de Resumos Expandidos. 1: 215-216.

Gioia S.M.C. 1997. Preparação da Metodologia Sm-Nd para Datação de Amostras Geológicas e sua Aplicação em Rochas das áreas de Firminópolis, Fazenda Nova e Americano do Brasil. Dissertação de Mestrado, Universidade de Brasília, Brasília, $121 \mathrm{p}$

Hasui Y. \& Almeida F.F.M. 1970. Geocronologia do centro-oeste brasileiro. Boletim da Sociedade Brasileira de Geologia, 19:5-26.

Lacerda Filho J.V., Camargo M.A., Wildncr W. 1995. Granitóide sin-tcctônico de Maratá. In: SBG- Núcleo Ccntro-Ocstc, V Simpósio de Geologia do Centro-Ocstc, Goiânia, Resumos, 66-67.

Lacerda Filho J.V. \& Oliveira C.C. 1994. Geologia da região sudeste de Goiás. In: SBG-Núclco Centro-Oeste, IV Simpósio de Geologia do Centro-Oeste, Brasília, Anais, 157-160.

Nilson A.A., Gioia S., Pimentel M.M. 1997. Idade Sm-Nd do Complexo Máfico-Ultramáfico de Americano do Brasil, Goiás e características isotópicas das rochas cncaixantes. In: SBGq VI Congresso Brasileiro de Geoquímica, Salvador, Anais.2:643-645.

Pimentel M.M. 1992. Reajuste do sistema isolópico Sm-Nd durante o Neoproterozóico em gnaisses do oeste de Goiás. Revista Brasileira de Geociências, 22:1-7.

Pimentel M.M. \& Fuck R.A. 1986. Geologia da seqüência vulcanossedimentar de Arenópolis (GO). Revista Brasileira de Geociências, 16:217-223.

Pimentel M.M. \& Fuck R.A. 1987. Origem c evolução das rochas metavulcânicas c metaplutônicas da região de Arenópolis (GO). Revista Brasileira de Geociências,n:2-14

Pimentel M.M. \& Fuck R.A. 1992a. Ncoprolero/.oic crustal accretion in central Brazil. Geology, 20:375-379.

Pimcntel M.M. \& Fuck R.A. 1992b. Origin of orthogneiss and metavolcanic rock units in western Goiás: Neoproterozoic crustal accretion in central Brazil. Gcochim. Brasil., 5:133-152
Pimcntel M.M. \& Fuck R.A. 1994. Geocronologia Rb-Sr da porção sudoeste do Maciço Mediano de Goiás. Revista Brasileira de Geociências, 24:104-111.

Pimentel M.M., Fuck R.A., Alvarenga C.J.S. 1996. Post-Brasiliano (Pan-African) high-K granitic magmatism in central Brazil: late Prccambrian/early Paleozoic extension. Precambrían Research, 80:217-238.

Pimcntel M.M., Fuck R.A., Cordani U.G., Kawashila K. 1985. Geocronologia de rochas graníticas e gnáissicas da região de Arenópolis-Piranhas, Goiás. Revista Brasileira de Geociências, 15:3-8

Pimentel M.M., Fuck R.A., Dardenne M.A., Ribeiro R.J.C. 1997b. Características isotópicas (S e Nd) c gcoquímicas do magmatismo granítico associado ao Grupo Araxá na região de Ipamcri, Goiás. In: SBG-Núclco Centro-Oeste, VI Simpósio de Geologia do Ccntro-Oeste, Cuiabá, Anais, 20-22.

Pimentcl M.M., Fuck R.A., Junges, S. 1998. New Sm-Nd isotopic constraints for the age of mctamorphic events in the Neoproterozoic Brasília Belt, central Brazil. In: International Basement Tectonics Association-DEGEO-UFOP, IV International Conference on Basement Tectonics, Ouro Preto, Abstracts, 50-52.

Pimcntel M.M., Hcaman L., Fuck R.A. 1991. U-Pb zircon and sphenc geochronology of late Protcrozoic volcanic arc rock units from southwestern Goiás, Central Brazil. Journal of South American Earth Sciences, 4:329-339.

Pimentel M.M., Whitchousc M.J., Viana M.G., Fuck R.A., Machado N. 1997a. The Mara Rosa arc in the Tocantins Province: Further evidence for Neoproterozoic crustal accretion in central Brazil. Precambrian Research, 81:299-310.

Pimentcl M.M., Fuck R.A., Botelho N.F. 1998. Granites and the geodynamic history of the Neoproterozoic Brasilia Belt, Central Brazil: a review. Lithos, in press.

Rodrigues J.B. 1996. Geocronologia e geoquímica da seqüência vulcanossedimentar de Iporá e rochas graníticas associadas. Dissertação de Mestrado. Universidade de Brasília, 101 p.

Seer H.J. 1985. Geologia, deformação e mineralização de cobre no complexo vulcanossedimentar de Bom Jardim de Goiás. Dissertação de Mestrado. Universidade de Brasília, Brasília, 190 pp.

Simões L.S.A. 1984. Geologia do Grupo Araxá na região de Mossâmedes-Goiás e as ocorrências minerais associadas. Dissertação de Mestrado, Universidade de Brasília, Brasília, 250pp.

Slricdcr A. \& Nilson A.A. 1992. Estudo petrológico de alguns fragmentos tcctônicos da melange ofiolítica cm Abadiânia (GO): I - O protolito dos corpos de serpentinito. Revista Brasileira de Geociências, 22:338-352.

Suita M.T.F., Kamo S.L., Krogh T.E., Fyfc W.S., Hartmann L.A. 1994. U-Pb ages from the high-grade Barro Alto mafic-ultramafic complex (Goiás, Central Brazil): middle Proterozoic continental mafic magmatism and Upper Proterozoic continental collision. In: Inter. Confer, on Gcochr. Cosmochr. and Isot. Geol., 8., Abstracts... Berkeley, USGS, p.309.

Trompcltc R. 1994. Geology of western Gondwana (2000-500 Ma). Pan-African-Brasiliano aggregation of South America and Africa. Rotterdam, Balkema, $350 \mathrm{p}$.

Viana M.G., Pimnctel M.M., Whitehouse M.J., Fuck R.A., Machado N. 1995.0 Arco Magmático de Mara Rosa, Goiás: Dados gcoquímicos e geocronológicos c suas implicações regionais. Revista Brasileira de Geociências, 25:111-123 